\title{
Determinants of Operational Efficiency in Asian Banking: A Two-stage Banking Model Analysis
}

\author{
Jonchi Shyu \\ Dept. of Business Administration, National Taiwan University of Science and Technology \\ 43, Sec. 4, Keelung Rd., Da'an Dist., Taipei 106, Taiwan \\ E-mail: jonchi.shyu@msa.hinet.net
}

\author{
Jia-Chi Lin \\ Dept. of Fashion Administration \& Management, St. John's University \\ 499, Section 4, Tam-King Road, Tamsui, Taipei 25135, Taiwan \\ E-mail: serena@mail.sju.edu.tw
}

\author{
Chen-Kuang $\mathrm{Wu}$ \\ Dept. of Business Administration \\ National Taiwan University of Science and Technology \\ 43, Sec. 4, Keelung Rd., Da'an Dist., Taipei 106, Taiwan \\ E-mail:wch322@ms16.hinet.net
}

Received: August 30, 2014 Accepted: Dec. 21, $2014 \quad$ Published: December 21, 2014

doi:10.5296/ajfa.v6i2.6244 URL: http://dx.doi.org/10.5296/ajfa.v6i2.6244

\begin{abstract}
This paper applies a two-stage banking model to analyze the operational efficiency of 137 Asian banks. Tobit regression model is also used to investigate the effect under the different operating environment and the characteristics of banks on banking efficiency. The empirical results show that technical inefficiency in the production stage for all the Asian banks is caused by pure technical inefficiency. In the intermediary stage, the banks' technical inefficiencies in China, Taiwan, and South Korea are mainly caused by pure technical inefficiency, whereas in Hong Kong, Malaysia, Thailand, Singapore and Philippines, it is caused by scale inefficiency. From the policy perspective, this study can help Asian banks
\end{abstract}




\section{Macrothink}

Asian Journal of Finance \& Accounting ISSN 1946-052X 2014, Vol. 6, No. 2

recognize whether their competition edges lie in acting more as a producer or an intermediary. The findings can also provide important references for banks in Asian countries to deliberate upon the capacities and niche in order to improve their competitive position in the financial market.

Keywords: Two-stage banking model, DEA, Tobit regression analysis, Asian banks, operational efficiency 


\section{Introduction}

In recent years, there has been an increasing interest in the study of banking efficiency in Asian countries (e.g. Lim and Randhawa, 2005; Ahmad et al., 2010; Ngo, 2012; Neupane, 2013; Sharma and Dalip, 2014). Banks, through financial intermediary and credit creation functions, settle capital supply and demand among different industries to help boost industrial development and capital preservation. Therefore, banking performance is closely related to the overall economic development of a country. Understanding the factors that affect banking performance can help banks to assess the adequacy of their current resource management and to allocate and apply resources more efficient, thereby greatly help the economic development of the countries in which they operate.

The financial environments in Asian countries become more open due to of globalization and many international banks tend to utilize their competitive strength in the Asian banking sectors when entering the Asian market. Asian banks, meanwhile, face a more competitive environment. They need to strengthen efficiency in areas wherein they already have an edge and to make up for their weaknesses in other areas. For example, they could use fewer resources to draw deposits in the production stage to make up for inefficiency in the intermediary stage (Denizer et al., 2007). Asian Banks also need to determine whether being a production unit or an intermediary can achieve better efficiency to meet their operating targets. Relevant methods include increasing market share, introducing new financial products, and organizational downsizing (Denizer et al., 2000, 2007). The banking efficiency literature has been dominated by studies in the U.S. and European countries. Berger and Humphrey (1997) survey 130 efficiency studies of financial institutions, of which very few address the application in Asian countries.

In this paper, a two-stage banking model approach (production and intermediation stage) is proposed for the efficiency evaluation for Asian banking firms. Data envelopment analysis (DEA) techniques are used to measure the efficiency of Asian banks. The empirical findings in this study can help Asian banks recognize whether their competitive edges lie in acting more as a producer or an intermediary, and how to improve their efficiency in the production stage and intermediary stage.

\section{Banking efficiency in Asian countries}

\subsection{Evaluation of banking efficiency}

In extant studies on bank performance, some scholars consider banks as production units (Benston, 1965; Ferrier et al., 1990; Shaffnit et al., 1997; Zenios et al., 1999), some view banks as intermediaries (Maudos and Pastor, 2003; Casu et al., 2003), and some believe that banks play both roles (Denizer et al., 2000; Athanassopoulos and Giokas, 2000). Benston (1965) first introduced the production approach that views financial institutions as providers of services for account holders. In this approach, outputs include all types of trading accounts and other services provided by banks, and inputs include employees, issued capital, and related costs. Elyasiani and Mehdian (1990a, 1990b) and Mester (1987) studied bank operating performance via the intermediary approach, outputs are viewed as the earning assets of banks, whereas deposits, capital, and labor are viewed as inputs. 


\section{Mll Macrothink}

The most important source of a bank's profit is interest incomes, which depends on the amount of corporate and consumer loans. Therefore, a bank's "selling ability" is important in the intermediation stage. If a bank's loanable funds are viewed as a product, the unit price of the product is interest rate on loans, and the revenue is interest incomes. In addition, the main source for a bank's loanable funds is the deposits drawn from capital owners. Therefore, deposits can be viewed as the "material" to create loans as a product in the production stage. The unit price of the material is interest rate on deposits, and its production cost is interest costs. The above arguments illustrate that the production and intermediation stages are two sides of the same coin. Denizer et al. (2000) was the first to connect bank production function with intermediary function, arguing that all banks have these two functions and that these functions are complementary. In their study of the banking industry in Turkey from 1970 to 1994, Denizer et al. (2000) define the bank inputs in the production stage as the banks' tangible assets, salary expenses, and interest costs, whereas the outputs are the deposits and related commission income. In the intermediation stage, the inputs are the deposits and operating costs (salary expenses are not included), whereas the outputs are the loans, related interest income, and commission income. The authors found that banking efficiency values for the two stages did not rise after the Turkish government implemented financial liberalization programs. The main reason for this phenomenon was that the country did not have a stable macroeconomic environment during the sample period. In addition, scale inefficiency was the main cause of low technical efficiency. Denizer et al. (2007) further applied the production and intermediary approaches to evaluate the factors that affecting banking efficiency in Turkey and found that both the GDP growth rate and the inflation rate (calculated using GDP deflators) were negatively correlated with the efficiency values for the two stages. During the sample period, the inflation rate fluctuated greatly, rising from $9 \%$ in the $1970 \mathrm{~s}$ to $85 \%$ in the $1980 \mathrm{~s}$, before falling to an average of $65 \%$ in the $1990 \mathrm{~s}$. Moreover, the GDP growth rates fluctuated wildly ranging from a low of $-6 \%$ to a high of $11 \%$. Such extreme fluctuations would increase uncertainty and risks for the banks. Meanwhile, high growth rates would induce banks to expand their loans and investment products, which would lower the overall quality of the banks' assets (Keeton, 1999). Hence, a successful financial reform program has to first build a stable economic and financial environment.

After the 1997 Asian financial crisis, many countries reformed their banks by closing universal banks, transferring bank assets to healthier banks, setting up core banking billing systems (the IT systems that dealt with business, accounting, and bills), transferring non-performing assets to government institutions or asset management companies, and adding new assets into banks for reorganization (Williams and Nguyen, 2005). They also adopted international standards of banking supervision and regulation to build a healthy financial environment such as laws regarding capital adequacy ratios, loan levels, and loan loss reserves (Lindgren et al., 2000).

\subsection{Cross-country analysis of bank efficiency}

In Lim and Randhawa' (2005) comparison of banking efficiency in Hong Kong and Singapore, which was based on banks playing the two roles with equal importance. The study assessed the overall efficiency through the average efficiency values for the production and 
intermediation stages. According to the empirical results, banking efficiency value for Singapore was higher in the production stage than that for Hong Kong. The main reason for this finding was that the Hong Kong Monetary Authority raised the interbank overnight rate (soaring to $300 \%$ on October 23,1997 ) to prevent speculators from attacking the Hong Kong dollar, which in turn led to a rise in capital costs. The 1997 financial crisis also made deposits in Hong Kong banks very unstable and caused the deposit growth rate to decline. The banks competed with one another, and increased their capital costs to gain deposits. However, the interest rate in Singapore was more stable than in Hong Kong. In this way, Singapore maintained a stable efficiency value in the production stage. Nevertheless, Hong Kong had a higher efficiency value in the intermediation stage mainly because Singapore had tremendously high capital adequacy ratio, reserve ratio, minimum liquid asset ( $18 \%$ of gross debt), and minimum cash balance (3\% of gross debt) requirements, in addition to conservative loan strategies. This economic scenario applies that, if the Singaporean government wishes to improve the performance of the banks as intermediaries, they need to loosen their regulations and create a more competitive environment, providing banks with motivation for more investment and loan activities.

Sufian (2009) assessed the factors determining banking efficiency in Thailand and Malaysia via Tobit regression analysis. In Malaysia banking sector, the author finds that in the operating approach, the scale of deposits to be positively correlated with efficiency and that the higher the market share a bank has, the more efficient it is. Meanwhile, the ratio of loans to total assets in the intermediary approach was found to be positively correlated with efficiency values. In contrast, the factor negatively correlated with efficiency is asset size, which means that the current asset size for banks in Malaysia is not sufficient for cost minimization. Notably, the ratio of loan loss reserves to total loans shows a positive correlation in the operating approach. This result can be explained by the skimping hypothesis of Berger and DeYoung (1997), which posits that an efficient bank usually tightens its costs in a short-term period to achieve long-term profits. This action will not only lower the costs of monitoring loans but also bring a high possibility of non-performing loans. Therefore, more reserves for non-performing loans are required. The ratio of non-interest expenses to total assets is negatively correlated with efficiency values in the value-added and operating approaches, but positively correlated with efficiency values in the intermediary approach. This result shows that Malaysia's bank may need to input more non-interest expenses to be a highly efficient intermediary. ${ }^{1}$

In the Thailand banking sector, the factor positively correlated with efficiency is the ratio of equity to assets, which shows significant positive correlation with all the approaches. Therefore, the lower the leverage of the Thailand's bank, the more efficient it is. Asset size has a significant positive relation to the value-added approach, which shows the existence of economy of scale. One factor that has a negative relationship with efficiency is the natural log of GDP in the value-added approach. This negative relationship may be due to the great

\footnotetext{
1 Sathye (2001) claim ed that high salaries and management expenses may lead to managers being more professional ${ }^{t}$ he ${ }^{\text {reby facilitating }}$ higher efficiency values.
} 
fluctuation in the GDP growth rate in Thailand during the sample period, which resulted in less demand for financial services and caused the default rate for loans to increase. ${ }^{2}$

As for the relation between market concentration ratio and efficiency, Berger and Humphrey (1997) indicated that (through a consolidation of 130 earlier studies of banking efficiency) market concentration ratio may be either positively or negatively correlated with banking efficiency. A positive correlation may be due to two possible reasons. First, the higher the market share of a firm, the more market power it has to negotiate prices and gain more returns. Second, in an efficient market structure, an efficient firm is able to produce outputs with low costs and thus gain higher returns. In contrast, the reason for a negative correlation is that the higher the market concentration ratio, the better a firm is able to negotiate prices. This allows big firms to lose their impetus for cost minimization and leads to rising costs and lower efficiency. This phenomenon is essentially the "Quiet Life Hypothesis" proposed by Hicks (1935). Al-Muharrami and Matthews (2009) evaluated the performance of the Arab Gulf Cooperation Council (GCC) banking industry in the context of the Market Power Hypotheses in the period of 1993 to 2002. The empirical results do not find any support for the Hick's "Quit Life" version of the market power hypothesis. Instead, GCC banks behaviour are consistent with the tradition Structure-Conduct-Performance (SCP) hypothesis where market structure helps to explain performance.

Based on the above studies, we can conclude that the ROA, asset size, loan loss reserves to total loans, non-interest expenses to total assets, equity to total assets, market concentration rate, and GDP growth rate have a significant effect on bank efficiency. However, do these factors have different effects on bank efficiency in the Asian banking industry? What are their effects on the production and intermediation stages? The answers to the above questions can provide better insights for Asian banks to enhance their efficiency and optimize their resource allocation. They can also be of future reference for other international banks when entering the Asian market.

\section{Methodology and variable selection}

Banking industries is one of the most complex financial services sector. A single-point evaluation cannot overall reflect the financial industries' multi-function ability (Paradi et al., 2011). Using DEA approach to evaluate the operational efficiency of multi- input and multi-output can provide directions for improvement to inefficiency (Zhu, 2000). Additionally, Sexton and Lewis (2003) and Abad et al. (2004) proposed that the superiority of two-stage DEA that represent the real operational process of firm in different stage of efficiency. Hence, this study followed the methodology used by Denizer et al. $(2000,2007)$ to measure the efficiency of commercial banks in the production and intermediation stages in Taiwan, China, Hong Kong, Singapore, South Korea, Philippines, Thailand and Malaysia.

\footnotetext{
2 Pasiouras (2008) measured the efficiency of 715 commercial banks in 2003 in 95 countries and found that GDP growth rates to be significantly negatively correlated with efficiency values in the intermediary approach. This explains how, although high GDP growth rates signify an increasing demand for banking services, banks may also face less pressure to control costs, leading to decreased efficiency. However, GDP and banking efficiency may also be positively correlated because a high GDP indicates that the country's economic environment is relatively strong. In this situation, the banking sector will do well to develop business and lower operating costs.
} 


\section{MIMacrothink}

The CCR model proposed by Charnes, Cooper, and Rhodes (1978), under the assumption of constant returns to scale (CRS), measures the technical efficiency (TE) value of decision-making units (DMUs).

The CCR dual model can be computed by

$$
\begin{gathered}
\operatorname{Min} \theta_{\mathrm{k}}-\varepsilon\left(\sum_{\mathrm{i}=1}^{\mathrm{m}} \mathrm{S}_{\mathrm{ik}}^{-}+\sum_{\mathrm{r}=1}^{s} \mathrm{~S}_{\mathrm{rk}}^{+}\right) \\
\text {St. } \sum_{\mathrm{j}=1}^{\mathrm{n}} \lambda_{\mathrm{j}} \mathrm{X}_{\mathrm{ij}}-\theta_{\mathrm{k}} X_{i k}+\mathrm{S}_{\mathrm{ik}}^{-}=0, \mathrm{i}=1 \ldots, \mathrm{m} \\
\sum_{\mathrm{j}=1}^{\mathrm{n}} \lambda_{\mathrm{j}} \mathrm{Y}_{\mathrm{rj}}-\mathrm{S}_{\mathrm{rk}}^{+}=\mathrm{Y}_{\mathrm{rk}}, \mathrm{r}=1 \ldots, \mathrm{s} \\
\lambda_{\mathrm{j}}, \mathrm{S}_{\mathrm{rk}}^{+}, \mathrm{S}_{\mathrm{ik}}^{-} \geq 0, \mathrm{j}=1 \ldots, \mathrm{n}
\end{gathered}
$$

where $Y_{r j}$ is the $r^{\text {th }}$ output in the $j^{\text {th }}$ DMU, $X_{i j}$ is the $i^{\text {th }}$ input in the $j^{\text {th }}$ DMU, $S_{r k}^{+}$is the slack variable of the $\mathrm{r}^{\text {th }}$ output in the $\mathrm{k}^{\text {th }}$ DMU, and $\mathrm{S}_{\mathrm{ik}}^{-}$is the slack variable of the $\mathrm{i}^{\text {th }}$ input in the $\mathrm{k}^{\text {th }}$ DMU. Here, $\lambda$ represents the weight of the linear combination of the reference set; $\varepsilon$ is one minimal positive number called the non-Archimedean small number; and $\theta$ is the relative technical efficiency.

As for Equation (1), the condition for a relatively efficient DMU is $\theta=1$ and $\mathrm{S}_{\mathrm{i}}^{-}=\mathrm{S}_{\mathrm{r}}^{+}=0$. Under these conditions, the DMU is on an efficient frontier. For inefficient DMUs, the input and output for evaluation on the production frontier can be calculated as $\sum_{\mathrm{j}=1}^{\mathrm{n}} \lambda_{\mathrm{j}} \mathrm{X}_{\mathrm{ij}}$ and $\sum_{\mathrm{j}=1}^{\mathrm{n}} \lambda_{\mathrm{j}} \mathrm{Y}_{\mathrm{ij}}$, while the constraint of equation (1) indicates $\sum_{\mathrm{j}=1}^{\mathrm{n}} \lambda_{\mathrm{j}} \mathrm{X}_{\mathrm{ij}}=\theta X_{\mathrm{ik}}-\mathrm{S}_{\mathrm{ik}}^{-}$for input and $\sum_{\mathrm{j}=1}^{\mathrm{n}} \lambda_{\mathrm{j}} \mathrm{Y}_{\mathrm{rj}}=\mathrm{Y}_{\mathrm{rk}}+\mathrm{S}_{\mathrm{rk}}^{+}$for output. Thus, an inefficient DMU can achieve optimal efficiency by reducing $\Delta \mathrm{X}_{\mathrm{ik}}$ input or increasing $\Delta \mathrm{Y}_{\mathrm{rk}}$ output, where

$$
\Delta \mathrm{X}_{\mathrm{ik}}=\mathrm{X}_{\mathrm{ik}}-\left(\theta_{\mathrm{k}} X_{\mathrm{ik}}-\mathrm{S}_{\mathrm{ik}}^{-}\right), \mathrm{i}=1, \ldots, \mathrm{m}
$$




$$
\Delta \mathrm{Y}_{\mathrm{rk}}=\left(\mathrm{Y}_{\mathrm{rk}}+\mathrm{S}_{\mathrm{rk}}^{+}\right)-\mathrm{Y}_{\mathrm{rk}}=\mathrm{S}_{\mathrm{rk}}^{+}, \quad \mathrm{r}=1, \ldots, \mathrm{S}
$$

The traditional CCR model uses the CRS assumption to measure the efficiency of DMUs. However, not all DMUs are under the operation of optimal scale, and operating inefficiency may be caused by the scale of DMUs, not by technical inefficiency. Due to this drawback, Banker et al. (1984) has proposed a revised model (the BCC model) that changes the CRS assumption to the variable returns to scale assumption. Under the variable returns to scale assumption, the technical efficiency in CRS (TE ${ }^{\mathrm{CRS}}$ ) is calculated as the product of pure technical efficiency (PTE) and scale efficiency (SE). Thus, causes for technical inefficiency include pure technical inefficiency and inefficiency from DMUs not operating in the optimal scale.

$$
\mathrm{TE}^{\mathrm{CRS}}=\mathrm{TE}^{\mathrm{VRS}} \times \mathrm{SE} \text {, and } \mathrm{TE}^{\mathrm{VRS}}=\mathrm{PTE}
$$

The present study measured banking technical efficiency via DEA and analyzed the effect of the operating environment and the characteristics of banks on banking efficiency through the Tobit regression model. Tobit analysis is a limited dependent variable model. When the dependent variable to be analyzed is truncated or censored, the concept of ordinary least square is not appropriate to calculate the regression coefficient. Under this condition, the Tobit model, which follows the idea of maximum likelihood estimation, is the more appropriate tool to estimate the regression coefficient. The general formula for the Tobit model is as follows:

$$
\begin{array}{ll}
Y_{i j}^{*}=X_{i j}^{\prime} \beta_{i j}+\varepsilon_{i j} & i=1,2, \ldots, m \quad j=1,2, \ldots, n \\
Y_{i j}=Y_{i j}^{*} & \text { if } Y_{i j}^{*}>0 \\
Y_{i j}=0 & \text { if } Y_{i j}^{*} \leq 0
\end{array}
$$

where $X_{i j}^{\prime}$ is the variable matrix of the $\mathrm{i}^{\text {th }}$ independent variable for the sample bank $\mathrm{j}$, and $Y_{i j}^{*}$ is the sample dependent variable to describe the $i^{\text {th }}$ dependent variable of the sample

bank j. $\varepsilon_{i j}$ is the residual value from the regression. In the Tobit regression model, each bank's technical efficiency is applied as a dependent variable. The efficiency value is a constant between 0 and 1 . When the efficiency value is equal to 1 , the bank is relatively efficient compared to other banks.

This study examines commercial banks in Asian banking sector from 2004 to 2008, including 29 banks in China, 19 in Hong Kong, 14 in South Korea, 19 in Malaysia, 10 in the Philippines, 14 in Thailand, 28 in Taiwan, and 4 in Singapore. The bank's financial statements were obtained from the BankScope database; banks without complete required information were not included, thus yielding the final sample of 137 banks in this study. Denizer et al. (2007) suggested that using the ratio of interest costs and interest incomes instead of the ratio of costs for deposits and loans in each stage. The weight is defined such that interest income per unit represents one unit of transaction in the intermediation stage. Moreover, one unit of interest cost equals the transaction per unit in the production stage. 


\section{NI Macrothink}

Therefore, the measure of the weight in the production stage is given as: weight $=$ interest costs / (interest costs + interest incomes). The weight in the intermediation stage is calculated as: weight $=$ interest incomes $/$ (interest costs + interest incomes).

The definitions of input and output variables in the two stages are as follows: the input variables in the production stage are (1) total resources owned by the bank (including physical and financial capital) $\times$ the weight in the production stage $=($ fixed assets + equity capital) $\times$ [interest costs / (interest costs + interest incomes)]; (2) non-interest operating expenses $\times$ the weight in the production stage; and (3) interest costs. The output variables in the production stage are (1) non-interest incomes and (2) total deposits. The input variables in the intermediation stage are (1) total resources owned by the bank (including physical and financial capital $) \times$ the weight in the intermediary stage $=($ fixed assets + equity capital $) \times$ [interest incomes / (interest costs + interest incomes)]; (2) non-interest operating expenses $\times$ the weight in the intermediation stage; and (3) total deposits. The output variables in the intermediation stage are (1) total loans and (2) banking service incomes (including interest, commission, and fees).

The factors that affect banking efficiency in the Tobit regression model are the following: ROA (return on assets) is defined as pre-tax net profit / total assets and is used to evaluate the effect of profitability on efficiency; LNTA (the natural log of total assets) evaluates the effect of a bank's scale on efficiency; LLP/Loan (loan loss reserves / loans) measures the effect of a bank's loan quality on efficiency [LLP/Loan is classified as a factor affecting bank efficiency in the intermediation stage only]; NIE/TA (non-interest expenses / total assets) evaluates the effect of operating costs on efficiency. E/TA (shareholders equity / total assets) measures the effect of leverage on efficiency; GDP growth rate: evaluates the effect of economic conditions on bank efficiency. The data for this variable come from the World Bank database; MCC (market concentration ratio): the total assets of the top three banks in a country divided by the total assets in the country's banking sector (Beck et al., 2006).

\section{Empirical Results}

\subsection{Operational efficiency in Asian banking}

As seen from Table 1, the average technical efficiency over five years in the production stage is 0.6940 in China, 0.7649 in Taiwan, 0.8007 in South Korea, 0.5170 in Hong Kong, 0.6589 in Thailand, 0.7516 in Malaysia, 0.7813 in the Philippines and 0.8907 in Singapore. On the other hand, the average technical efficiency over five years in the intermediation stage is 0.8284 in China, 0.8846 in Taiwan, 0.7036 in South Korea, 0.7841 in Hong Kong, 0.6429 in Thailand, 0.7792 in Malaysia, 0.8362 in the Philippines and 0.8458 in Singapore. 
Table 1. Efficiency value of two-stages banking model

\begin{tabular}{|c|c|c|c|c|c|c|c|}
\hline \multirow{2}{*}{ Country } & \multirow{2}{*}{ year } & \multicolumn{3}{|c|}{ Production stage } & \multicolumn{3}{|c|}{ Intermediation stage } \\
\hline & & $\mathrm{TE}$ & PTE & SE & $\mathrm{TE}$ & PTE & SE \\
\hline \multirow{6}{*}{ China } & 2008 & 0.6500 & 0.7300 & 0.8963 & 0.8347 & 0.8960 & 0.9339 \\
\hline & 2007 & 0.6952 & 0.7653 & 0.9138 & 0.8286 & 0.8889 & 0.9352 \\
\hline & 2006 & 0.6890 & 0.7684 & 0.8963 & 0.8410 & 0.8877 & 0.9496 \\
\hline & 2005 & 0.7072 & 0.7800 & 0.9066 & 0.8249 & 0.8708 & 0.9501 \\
\hline & 2004 & 0.7288 & 0.7921 & 0.9164 & 0.8130 & 0.8819 & 0.9255 \\
\hline & $04 \sim 08$ & 0.6940 & 0.7672 & 0.9059 & 0.8284 & 0.8850 & 0.9389 \\
\hline \multirow{6}{*}{ Taiwan } & 2008 & 0.6953 & 0.7443 & 0.9266 & 0.8931 & 0.9229 & 0.9682 \\
\hline & 2007 & 0.6870 & 0.7298 & 0.93883 & 0.9020 & 0.9372 & 0.9637 \\
\hline & 2006 & 0.7458 & 0.7932 & 0.9430 & 0.8959 & 0.9307 & 0.9637 \\
\hline & 2005 & 0.8218 & 0.8790 & 0.9364 & 0.8783 & 0.9041 & 0.9724 \\
\hline & 2004 & 0.8747 & 0.9436 & 0.9211 & 0.8538 & 0.8848 & 0.9678 \\
\hline & $04 \sim 08$ & 0.7649 & 0.8180 & 0.9331 & 0.8846 & 0.9159 & 0.9671 \\
\hline \multirow{6}{*}{$\begin{array}{l}\text { South } \\
\text { Korea }\end{array}$} & 2008 & 0.7990 & 0.8388 & 0.9572 & 0.8039 & 0.8786 & 0.9174 \\
\hline & 2007 & 0.7591 & 0.7961 & 0.9590 & 0.7353 & 0.8154 & 0.9112 \\
\hline & 2006 & 0.7627 & 0.8055 & 0.9274 & 0.6830 & 0.7498 & 0.9220 \\
\hline & 2005 & 0.8200 & 0.8721 & 0.9199 & 0.6206 & 0.7051 & 0.8965 \\
\hline & 2004 & 0.8629 & 0.9194 & 0.9267 & 0.6753 & 0.7585 & 0.9025 \\
\hline & $04 \sim 08$ & 0.8007 & 0.8464 & 0.9381 & 0.7036 & 0.7815 & 0.9099 \\
\hline \multirow{6}{*}{ Hong Kong } & 2008 & 0.5167 & 0.5623 & 0.9454 & 0.7639 & 0.8816 & 0.8743 \\
\hline & 2007 & 0.4824 & 0.5353 & 0.9227 & 0.8941 & 0.9706 & 0.9218 \\
\hline & 2006 & 0.4147 & 0.4737 & 0.9001 & 0.8659 & 0.9557 & 0.9084 \\
\hline & 2005 & 0.4541 & 0.5074 & 0.9206 & 0.7371 & 0.8822 & 0.8475 \\
\hline & 2004 & 0.7172 & 0.7904 & 0.9186 & 0.6598 & 0.8042 & 0.8359 \\
\hline & $04 \sim 08$ & 0.5170 & 0.5738 & 0.9215 & 0.7841 & 0.8989 & 0.8776 \\
\hline \multirow{6}{*}{ Thailand } & 2008 & 0.613 & 0.7023 & 0.8882 & 0.6437 & 0.8232 & 0.7946 \\
\hline & 2007 & 0.508 & 0.5705 & 0.9007 & 0.6902 & 0.8796 & 0.7909 \\
\hline & 2006 & 0.542 & 0.6232 & 0.8890 & 0.7321 & 0.9143 & 0.8042 \\
\hline & 2005 & 0.812 & 0.8539 & 0.9429 & 0.5867 & 0.7302 & 0.8153 \\
\hline & 2004 & 0.819 & 0.8924 & 0.9115 & 0.5620 & 0.7173 & 0.8064 \\
\hline & $04 \sim 08$ & 0.659 & 0.7285 & 0.9065 & 0.6429 & 0.8129 & 0.8023 \\
\hline \multirow{6}{*}{ Malaysia } & 2008 & 0.7495 & 0.8018 & 0.9380 & 0.8236 & 0.9067 & 0.9072 \\
\hline & 2007 & 0.7359 & 0.7945 & 0.9246 & 0.8166 & 0.9179 & 0.8913 \\
\hline & 2006 & 0.7556 & 0.8245 & 0.9177 & 0.7767 & 0.8839 & 0.8849 \\
\hline & 2005 & 0.7297 & 0.7851 & 0.9218 & 0.7450 & 0.8890 & 0.8439 \\
\hline & 2004 & 0.7871 & 0.8392 & 0.9251 & 0.7340 & 0.8908 & 0.8270 \\
\hline & $04 \sim 08$ & 0.7516 & 0.8090 & 0.9254 & 0.7792 & 0.8976 & 0.8709 \\
\hline
\end{tabular}




\begin{tabular}{|c|c|c|c|c|c|c|c|}
\hline & 2008 & 0.8710 & 0.9330 & 0.9301 & 0.8585 & 0.9488 & 0.9035 \\
& 2007 & 0.8447 & 0.9171 & 0.9165 & 0.7963 & 0.9269 & 0.8601 \\
& 2006 & 0.8265 & 0.9014 & 0.9131 & 0.7961 & 0.9007 & 0.8890 \\
& 2005 & 0.6904 & 0.8264 & 0.8350 & 0.8637 & 0.9645 & 0.8947 \\
& 2004 & 0.6739 & 0.8115 & 0.8357 & 0.8666 & 0.9230 & 0.9371 \\
& $04 \sim 08$ & 0.7813 & 0.8778 & 0.8861 & 0.8362 & 0.9328 & 0.8969 \\
\hline \multirow{5}{*}{ Singapore } & 2008 & 0.9116 & 0.9809 & 0.9295 & 0.8415 & 0.9347 & 0.8768 \\
& 2007 & 0.7995 & 0.8927 & 0.9030 & 0.8761 & 0.9691 & 0.8948 \\
& 2006 & 0.8584 & 0.8969 & 0.9529 & 0.9054 & 1.0000 & 0.9054 \\
& 2005 & 0.8889 & 0.9470 & 0.9377 & 0.8431 & 0.9500 & 0.8866 \\
& 2004 & 0.9951 & 1.0000 & 0.9951 & 0.7630 & 0.8427 & 0.9047 \\
& $04 \sim 08$ & 0.8907 & 0.9435 & 0.9437 & 0.8458 & 0.9393 & 0.8937 \\
\hline
\end{tabular}

Note: The TE 、 PTE and SE efficiency value are bounded between 0 and 1 .

Using the Wilcoxon Signed-Rank test, Table 2 shows that the country wherein TE in the production stage is significantly higher than that in the intermediation stage is South Korea. In contrast, the countries wherein the TE in the intermediation stage is significantly higher than that in the production stage are China, Hong Kong, and Taiwan.

Table 2. The Wilcoxon Signed-Rank test of difference on TE between the production and intermediation stage

\begin{tabular}{|l|c|c|c|}
\hline country & Z Statistic & $\begin{array}{c}\text { P - value } \\
\text { (Two-tailed) }\end{array}$ & $\begin{array}{l}\text { Negative or positive } \\
\text { for the rating basis }\end{array}$ \\
\hline China & -5.96 & $0.00^{*}$ & - \\
Hong Kong & -6.90 & $0.00^{*}$ & - \\
Singapore & -0.62 & 0.53 & + \\
South Korea & -3.17 & $0.00^{*}$ & + \\
Malaysia & -1.50 & 0.13 & - \\
Philippines & -1.32 & 0.18 & - \\
Thailand & -0.45 & 0.64 & - \\
Taiwan & -6.42 & $0.00^{*}$ & + \\
\hline
\end{tabular}

Note: * indicates significant at $5 \%$ level.

Low technical efficiency may be caused by an unsuitable operational scale; however, management cannot control this problem in the short term. This kind of inefficiency requires scale adjustment in the long run. In contrast, pure technical inefficiency is under the control of managers and needs to be improved immediately. Thus, pure technical inefficiency is seperated from technical efficiency to disclose how much of technical inefficiency is come from pure technical inefficiency. This information can provide managers with a reference for improving their operational decisions and resources allocation. 
By comparing PTE and SE, on average, we can see that technical inefficiency in the production stage in all the countries is caused by pure technical inefficiency. In the intermediation stage, the technical inefficiencies in China, Taiwan, and South Korea are mainly caused by pure technical inefficiency, whereas in Hong Kong, Malaysia, Thailand, Singapore and the Philippines, it is caused by scale inefficiency. When technical inefficiency is caused by low pure technical inefficiency, the banks should strive to improve management skills and resource allocations to enhance their efficiency. If scale inefficiency is the main reason for technical inefficiency, banks should examine whether they are currently operating on an increasing or decreasing returns to scale. If they are in the stage of increasing returns to scale, these banks should increase inputs/outputs to enlarge their scale. In contrast, if they are operate at decreasing returns to scale, the banks should decrease inputs/outputs to the point of CRS as their optimal operating scale.

\subsection{Factors affecting Asian banking efficiency}

The present study uses TE as the dependent variable in the production and intermediation stages and economic environments and the banks' characters as explanatory variables to examine the factors affecting Asian banking efficiency through Tobit regression analysis. Base on Table 3, the factors that affect banking efficiency in each stage are the following: ROA shows a positive relationship with efficiency values in Hong Kong, Malaysia, the Philippines and Taiwan in the production stage; and in both the production and intermediation stages in Thailand. This result indicates that the higher the ability banks can generate profit from assets, the higher their efficiency.

In the production stage, concerning the impact of bank size, LNTA has positive effect on efficiency values in China, South Korea, the Philippines and Taiwan banks. The finding is consistent with the study of Chen and Yang (2011) on Chinese and Taiwan banks. The authors demonstrate that scale efficiency change is the key factor to inducing the productivity growth for the banks of China and Taiwan. In the intermediation stage, LNTA has positive effect on efficiency values in South Korea banks; however, it is negatively related to the efficiency values in the Philippines and Thailand banks. For the banks in the Philippines, LNTA has positive effect on efficiency values in the production stage, but is negatively effect bank efficiency in the intermediation stage. This result shows that the banks in the Philippines need to rearrange their assets allocation between two stages.

In the intermediation stage, the LLP/TL ratio is positively related to the efficiency values in Hong Kong and Thailand banks. This result confirms that Berger and DeYoung's skimping hypothesis exist in Hong Kong and Thailand banks. In the production stage, NIE/TA is positively related to bank efficiency values in the Philippines, but is negatively related in China and Malaysia. In the intermediation stage, the variable is positively related to the bank efficiency values in Singapore, but is negatively related to bank efficiency values in the Philippines and Thailand. The findings that NIE/TA is negatively related to efficiency value suggest that those banks need to increase non-interest operating costs (i.e., management expenses) to enhance their technical efficiency. 
E/TA being negatively related to efficiency means that the more the leverage a bank has, the lower the efficiency and vice versa. In the production stage, E/TA is positively related to bank efficiency values in China, but is negatively related in Malaysia, Singapore, Thailand, and Taiwan. In the intermediation stage, E/TA is positively related to bank efficiency values in Hong Kong and the Philippines, but is negatively related in Singapore and Thailand. MCC represents the relation between market structure and efficiency. In the production stage, MCC is positively related to bank efficiency values in Hong Kong, the Philippines, Singapore and Thailand, whereas it is negatively related in South Korea and Taiwan. In the intermediation stage, the variable is positively related to efficiency values in South Korea and Taiwan, but is negatively related in Singapore and Thailand. The coefficient of MCC has completely different results in the two stages in Singapore, Thailand, South Korea and Taiwan, indicating that the banks in Singapore and Thailand overlook their operating efficiency in the intermediation stage, and banks in South Korea and Taiwan need to increase (reduce) consolidation in the intermediation (production) stage to improve efficiency.

Table 3. Tobit regression analysis for Asian banks in production and intermediation stages

\begin{tabular}{|c|c|c|c|c|c|c|}
\hline \multirow{2}{*}{$\begin{array}{l}\text { Dependent: TE } \\
\text { China }\end{array}$} & \multicolumn{3}{|c|}{ Production stage } & \multicolumn{3}{|c|}{ Intermediation stage } \\
\hline & Coefficient & t-statistic & $\mathrm{P}>|\mathrm{t}|$ & Coefficient & t-statistic & $\mathrm{P}>|\mathrm{t}|$ \\
\hline ROA(pretax) & -0.0482 & -1.50 & 0.14 & -0.0274 & -0.95 & 0.35 \\
\hline LNTA & $0.0245^{* * *}$ & 2.58 & 0.01 & 0.0008 & 0.10 & 0.92 \\
\hline LLP/TL & & & & 0.0277 & 1.36 & 0.18 \\
\hline NIE/TA & $-0.3206^{* * *}$ & -5.48 & 0.00 & 0.0614 & 1.24 & 0.22 \\
\hline $\mathrm{E} / \mathrm{TA}$ & $0.0069^{* *}$ & 2.47 & 0.02 & 0.0015 & 0.59 & 0.56 \\
\hline GDP growth & 0.0140 & 1.19 & 0.24 & 0.0017 & 0.16 & 0.87 \\
\hline $\mathrm{MCC}$ & 0.0282 & 1.65 & 0.10 & -0.0067 & -0.46 & 0.65 \\
\hline intercept & -1.6031 & -1.12 & 0.26 & 1.1993 & 0.97 & 0.33 \\
\hline Hong Kong & & & & & & \\
\hline ROA(pretax) & $0.1493 * * *$ & 4.94 & 0.00 & 0.0149 & 0.55 & 0.59 \\
\hline LNTA & 0.0167 & 0.88 & 0.38 & -0.0089 & -0.47 & 0.64 \\
\hline $\mathrm{LLP} / \mathrm{TL}$ & & & & $0.1360 *$ & 1.71 & 0.09 \\
\hline NIE/TA & 0.0392 & 0.96 & 0.34 & -0.0181 & -0.42 & 0.68 \\
\hline E/TA & 0.0066 & 0.85 & 0.40 & $0.0153 * *$ & 2.02 & 0.05 \\
\hline GDP growth & $-0.0227 *$ & -1.74 & 0.09 & $0.0428 * * *$ & 3.13 & 0.00 \\
\hline $\mathrm{MCC}$ & $0.5519^{* *}$ & 2.04 & 0.05 & 0.2225 & 0.82 & 0.42 \\
\hline intercept & $-39.5322 * *$ & -2.03 & 0.05 & -15.4345 & -0.79 & 0.43 \\
\hline South Korea & & & & & & \\
\hline ROA(pretax) & 0.0749 & 0.95 & 0.35 & -0.0240 & -0.44 & 0.66 \\
\hline LNTA & 0.0121 & 0.58 & 0.56 & $0.0363 * * *$ & 2.74 & 0.01 \\
\hline LLP/TL & & & & -0.0242 & -0.65 & 0.52 \\
\hline NIE/TA & 0.0504 & 1.37 & 0.17 & 0.0089 & 0.71 & 0.48 \\
\hline E/TA & 0.0168 & 0.50 & 0.62 & $-0.0899 * * *$ & -4.31 & 0.00 \\
\hline GDP growth & 0.0197 & 1.05 & 0.30 & -0.0076 & -0.60 & 0.55 \\
\hline $\mathrm{MCC}$ & $-0.0167 *$ & -1.91 & 0.06 & $0.0217 * * *$ & 3.64 & 0.00 \\
\hline intercept & 0.9739 & 1.56 & 0.13 & $-0.6684 *$ & -1.77 & 0.08 \\
\hline Malaysia & Coefficient & t-statistic & $\mathrm{P}>|\mathrm{t}|$ & Coefficient & t-statistic & $\mathrm{P}>|\mathrm{t}|$ \\
\hline ROA(pretax) & $0.1032 * * *$ & 4.49 & 0.00 & 0.0441 & 1.21 & 0.23 \\
\hline
\end{tabular}




\section{Macrothink}

\begin{tabular}{|c|c|c|c|c|c|c|}
\hline $\begin{array}{l}\text { LNTA } \\
\text { LLP/TL } \\
\text { NIE/TA } \\
\text { E/TA } \\
\text { GDP growth } \\
\text { MCC } \\
\text { intercept }\end{array}$ & $\begin{array}{l}0.0221 \\
-0.1338 * * * \\
-0.0089 * * * \\
0.0080 \\
-0.0074 \\
0.7609 *\end{array}$ & $\begin{array}{c}-2.74 \\
-2.64 \\
0.87 \\
-1.43 \\
1.85\end{array}$ & $\begin{array}{l}0.01 \\
0.01 \\
0.39 \\
0.16 \\
0.07\end{array}$ & $\begin{array}{r}0.0230 \\
0.0261 \\
0.0104 \\
-0.0010 \\
-0.0033 \\
0.0078 \\
0.0169\end{array}$ & $\begin{array}{c}0.88 \\
1.21 \\
0.21 \\
-0.23 \\
-0.34 \\
1.43 \\
0.03\end{array}$ & $\begin{array}{l}0.38 \\
0.23 \\
0.83 \\
0.82 \\
0.74 \\
0.16 \\
0.97\end{array}$ \\
\hline $\begin{array}{l}\text { Philippines } \\
\text { ROA(pretax) } \\
\text { LNTA } \\
\text { LLP/TL } \\
\text { NIE/TA } \\
\text { E/TA } \\
\text { GDP growth } \\
\text { MCC } \\
\text { intercept }\end{array}$ & $\begin{array}{c}0.0883 * * * \\
0.1435 * * * \\
0.1379 * * * \\
0.0043 \\
-0.0389 \\
0.0090^{* * *} \\
-2.4247 * * *\end{array}$ & $\begin{array}{c}3.23 \\
5.70 \\
\\
3.24 \\
0.80 \\
-1.58 \\
3.51 \\
-3.47\end{array}$ & $\begin{array}{l}0.00 \\
0.00 \\
\\
0.00 \\
0.43 \\
0.12 \\
0.00 \\
0.00\end{array}$ & $\begin{array}{l}-0.0195 \\
-0.1430^{* * *} \\
-0.0167 \\
-0.1411^{* * *} \\
0.0151^{* *} \\
0.0076 \\
0.0030 \\
3.5976^{* * *}\end{array}$ & $\begin{array}{l}-0.66 \\
-6.48 \\
-0.83 \\
-3.52 \\
2.59 \\
0.34 \\
1.22 \\
5.74 \\
\end{array}$ & $\begin{array}{l}0.52 \\
0.00 \\
0.41 \\
0.00 \\
0.01 \\
0.73 \\
0.23 \\
0.00 \\
\end{array}$ \\
\hline $\begin{array}{l}\text { Singapore } \\
\text { ROA(pretax) } \\
\text { LNTA } \\
\text { LLP/TL } \\
\text { NIE/TA } \\
\text { E/TA } \\
\text { GDP growth } \\
\text { MCC } \\
\text { intercept }\end{array}$ & $\begin{array}{c}0.0687^{*} \\
-0.0287 \\
0.1559 \\
-0.0191^{* *} \\
0.0101 \\
0.0242^{* * *} \\
-0.9020\end{array}$ & $\begin{array}{c}2.10 \\
-1.49 \\
\\
1.60 \\
-2.24 \\
1.17 \\
3.01 \\
-1.14\end{array}$ & $\begin{array}{l}0.06 \\
0.16 \\
\\
0.13 \\
0.04 \\
0.26 \\
0.01 \\
0.28 \\
\end{array}$ & $\begin{array}{c}-0.0144 \\
0.0074 \\
-0.0626 \\
0.3825^{* * *} \\
-0.0396^{* *} \\
-0.0182^{* * *} \\
-0.0193^{* * *} \\
2.8610^{* * *}\end{array}$ & $\begin{array}{c}-0.30 \\
0.31 \\
-0.98 \\
4.22 \\
-2.76 \\
-4.24 \\
-4.63 \\
3.53 \\
\end{array}$ & $\begin{array}{l}0.77 \\
0.77 \\
0.36 \\
0.00 \\
0.03 \\
0.00 \\
0.00 \\
0.01\end{array}$ \\
\hline $\begin{array}{l}\text { Thailand } \\
\text { ROA(pretax) } \\
\text { LNTA } \\
\text { LLP/TL } \\
\text { NIE/TA } \\
\text { E/TA } \\
\text { GDP growth } \\
\text { MCC } \\
\text { intercept }\end{array}$ & $\begin{array}{l}0.0527^{* *} \\
-0.0156 \\
-0.0316 \\
-0.0195^{* * *} \\
0.0250 \\
0.0631^{* * *} \\
-1.9853\end{array}$ & $\begin{array}{c}2.37 \\
-0.55 \\
\\
-0.83 \\
-3.36 \\
1.36 \\
2.82 \\
-1.56\end{array}$ & $\begin{array}{l}0.02 \\
0.59 \\
\\
0.41 \\
0.00 \\
0.18 \\
0.01 \\
0.12\end{array}$ & $\begin{array}{c}0.0456^{* * *} \\
-0.0774^{* * *} \\
0.0312^{* *} \\
-0.1249^{* * *} \\
-0.0256^{* * *} \\
-0.0031 \\
-0.0298^{* *} \\
4.0275^{* * *}\end{array}$ & $\begin{array}{c}2.95 \\
-4.37 \\
2.19 \\
-5.52 \\
-5.02 \\
-0.28 \\
-2.17 \\
4.98\end{array}$ & $\begin{array}{l}0.01 \\
0.00 \\
0.03 \\
0.00 \\
0.00 \\
0.78 \\
0.03 \\
0.00\end{array}$ \\
\hline $\begin{array}{l}\text { Taiwan } \\
\text { ROA(pretax) } \\
\text { LNTA } \\
\text { LLP/TL } \\
\text { NIE/TA } \\
\text { E/TA } \\
\text { GDP growth } \\
\text { MCC } \\
\text { intercept }\end{array}$ & $\begin{array}{c}0.0544 * * * \\
0.0498 * * * \\
0.0162 \\
-0.0069 * * * \\
-0.0057 \\
-0.0450 * * * \\
1.0612 * * * \\
\end{array}$ & $\begin{array}{c}6.24 \\
3.43 \\
\\
0.91 \\
-5.07 \\
-1.03 \\
-4.52 \\
2.70\end{array}$ & $\begin{array}{l}0.36 \\
0.00 \\
0.31 \\
0.00 \\
0.01 \\
\end{array}$ & $\begin{array}{l}-0.0085 \\
-0.0018 \\
-0.0023 \\
-0.0101 \\
-0.0006 \\
0.0019 \\
0.0097^{*} \\
0.6714^{* * *}\end{array}$ & $\begin{array}{c}-1.11 \\
-0.23 \\
-0.44 \\
-1.05 \\
-0.49 \\
0.64 \\
1.73 \\
3.12 \\
\end{array}$ & $\begin{array}{l}0.27 \\
0.82 \\
0.66 \\
0.30 \\
0.63 \\
0.52 \\
0.09 \\
0.00 \\
\end{array}$ \\
\hline
\end{tabular}

Note: $*$ indicates significant at $10 \%$ level, $* *$ indicates significant at $5 \%$ level, $* * *$ indicates significant at $1 \%$ level.

In the production stage, the GDP growth rate is negatively related to efficiency values in Hong Kong. In the intermediation stage, the variable is positively related to efficiency values 
in Hong Kong, but is negatively related in Singapore. The negative relationship of GDP growth rate with efficiency values in the production stage in Hong Kong may be the consequence of funds moving toward real estate and stocks during the sample period combined with relatively fewer deposit incentives. Between 1999 and 2003, the average M1/M2 in Hong Kong was 7.97\%; however, from 2004 to 2008, it became 10.34\%, which means that funds were gradually being withdrawn from bank deposits. Although GDP growth rates increased, the ability of banks to draw deposits decreased, thereby lowering the efficiency values in the production stage. This variable is negatively related to efficiency values in Singapore banks in the intermediation stage. Although the banks in Singapore enjoy high GDP growth rates, ${ }^{3}$ they may face less pressure to control their operation costs, leading to dropping of efficiency values (Pasiouras,2008).

\section{Conclusion}

Nearly all extant banking efficiency studies are limited to the use of either intermediary or production approaches to examine the performance of the banking industry. Using only one approach, however, cannot provide a comprehensive evaluation of banking efficiency. In practice, a bank has to consider the mutual effects of the two aspects. This study find that South Korea has a higher TE in the production stage than in the intermediation stage from 2004 to 2008, whereas China, Hong Kong, and Taiwan have higher TE in the intermediation stage. Banks with a significantly higher TE in the production (intermediation) stage than in the intermediation (production) stage demonstrate strengths in production (intermediary) capability. Therefore, when local banks in South Korea facing foreign competition, they could to take advantage of their strength in the production stage to overcome the challenge. Similarly, local banks in China, Hong Kong, Taiwan need to exploit their advantages as intermediary to compete with foreign banks.

Additionally, most Asian banks need to enhance their management skills in production stage in order to generate higher production efficiency. Banks in China, Taiwan and South Korean have to strength their management abilities as an intermediary to enhance operating efficiency. However, banks in Hong Kong, Malaysia, Thailand, Singapore and the Philippines could increase the scale of banks to improve operating efficiency in intermediation stage. By looking at the factors that affect TE, the banks in the Philippines could transfer some management resources from the intermediation stage to the production stage toward obtaining a higher efficiency. Banks in Hong Kong and Thailand, in the meantime, should ensure the quality of loans in the future. If banks in China wish to improve TE in the production stage, they need to lower their operating costs and debt ratios. Banks in South Korean and Taiwan, in contrast, can improve efficiency in the intermediation stage through bank consolidation. Moreover, particularly noteworthy is the fact that banks in Singapore and Thailand seem to have a "Quiet Life" attitude, in which they should pay more attention to operating costs in the intermediation stage.

\footnotetext{
${ }^{3}$ The GDP growth rates of Singapore from 2004 to 2008 were $14.15 \%, 8.6 \%, 9.85 \%, 13.78 \%$, and $2.31 \%$, respectively.
} 


\section{References}

Abad, C., S.A. Thore, \& J. Laffarge. (2004). Fundamental analysis of stocks by two-stage DEA. Managerial and Decision Economics, 25(5), 231-241. http://dx.doi.org/10.1002/mde.1145

Ahmad, N.H., A.N.M. Noor, \& F. Sufian. (2010). The efficiency of Islamic banks: empirical evidence from the Asian countries' Islamic banking sectors. Journal for International Business and Entrepreneurship Development, 5, 154-166. http://dx.doi.org/10.1504/JIBED.2010.036999

Al-Muharrami, S.K.M. (2009). Market power versus efficient-structure in Arab GCC banking. Applied Financial Economics, 19, 1487-1496. http://dx.doi.org/10.1080/09603100902845478

Athanassopoulos, A.D., \& D. Giokas. (2000). The use of data envelopment analysis in banking institutions: Evidence from the commercial bank of Greece. Interfaces, 30(2), 81-95. http://dx.doi.org/10.1287/inte.30.2.81.11678

Banker, R.D., A. Charnes, \& W.W. Cooper. (1984). Some models for estimating technical and scale inefficiencies in data envelopment analysis. Management Science, 30(9), 1078-1092. http://dx.doi.org/10.1287/mnsc.30.9.1078

Beck, T., A. Demirgüç-Kunt, \& R. Levine. (2006). Bank concentration, competition, and crises: First results. Journal of Banking and Finance, 30(5), 1581-1603. http://dx.doi.org/10.1016/j.jbankfin.2005.05.010

Benston, G.J. (1965). Branch banking and economies of scale. Journal of Finance, 20(2), 312-331. http://dx.doi.org/10.1111/j.1540-6261.1965.tb00212.x

Berger, A.N., \& D.B. Humphrey. (1997). Efficiency of financial institution: International survey and directions for future research. European Journal of Operational Research, 98(2), 175-212. http://dx.doi.org/10.1016/S0377-2217(96)00342-6

Berger, A.N., \& R. DeYoung. (1997). Problem Loans and Cost Efficiency in Commercial Banks. Journal of Banking and Finance, 21(6), 849-870. http://dx.doi.org/10.1016/S0378-4266(97)00003-4

Casu, B., C. Girardone, \& P. Molyneux. (2003). Productivity change in European banking: A comparison of parametric and nonparametric approaches. Journal of Banking and Finance, 28(10), 2521-2540. http://dx.doi.org/10.1016/j.jbankfin.2003.10.014

Charnes, A., W. Cooper, \& E. Rhodes. (1978). Measuring the efficiency of decision making units. European Journal of Operational Research, 2(4), 429-444. http://dx.doi.org/10.1016/0377-2217(78)90138-8

Chen, K.H., \& H.Y. Yang. (2011). A cross-country comparison of productivity growth using the generalised metafrontier malmquist productivity index with application to banking industries in Taiwan and China. Journal of Productivity Analysis, 35, 197-212. http://dx.doi.org/10.1007/s11123-010-0198-7 
Denizer, C.A., M. Dinc, \& M. Tarimcilar. (2000). Measuring efficiency in the pre and post liberalization environment: Evidence from the Turkish banking system. World Bank Policy Research Working Paper.

. (2007). Financial liberalization and banking efficiency: Evidence from Turkey.

Journal of Productivity Analysis, 27(3), 177-195.

http://dx.doi.org/10.1007/s11123-007-0035-9

Elyasiani, E. and S. Mehdian. (1990a). Efficiency in the commercial banking industry: a production frontier approach. Applied Economics, 22(4), 539-551. http://dx.doi.org/10.1080/00036849000000010

- (1990b). A nonparametric approach to measurement of efficiency and technological change: The case of large U.S. commercial banks. Journal of Financial Services Research, 4(2), 154-168.

Ferrier, G., C. Lovell, \& A.K. Mehdian. (1990). Measuring cost efficiency in banking: Econometric and linear programming evidence. Journal of Econometrics, 46(1-2), 229-245. http://dx.doi.org/10.1016/0304-4076(90)90057-Z

Hicks, J. (1935). Annual survey of economic theory: The theory of monopoly. Econometrica, 3(1), 1-20. http://dx.doi.org/10.2307/1907343

Keeton, W. (1999). Does faster loan growth lead to higher loan losses? Economic Review, Federal Reserve Bank of Kansas City, second quarter, 57-75.

Lim, G.H., \& D.S. Randhawa. (2005). Competition, liberalization and efficiency: Evidence from a two-stage banking model on banks in Hong Kong and Singapore. Managerial Finance, 31(1), 52-77. http://dx.doi.org/10.1108/03074350510769479

Lindgren, C.J., T.J.T. Balino, C. Enoch, A.M. Gulde, M. Quintyn, \& L. Teo. (2000). Financial sector crisis and restructuring: lessons from Asia', IMF Occasional Paper No. 188.

Maudos, J., \& J.M. Pastor. (2003). Cost and profit efficiency in the Spanish banking sector (1985-1996): a nonparametric approach. Applied Financial Economics, 13(1), 1-12. http://dx.doi.org/10.1080/09603100110086087

Mester, L.J. (1987). Efficient production of financial services: scale and scope economies. Business Review, Federal Reserve Bank of Philadelphia January/February, 15-25.

Neupane, B. (2013). Efficiency and productivity of commercial banks in Nepal: A malmquist index approach. Asian Journal of Finance \& Accounting, 5(2), 220-243. http://dx.doi.org/10.5296/ajfa.v5i2.4326

Ngo, D.T. (2012). Measuring the performance of the banking system: Case of Vietnam (1990-2010). Journal of Applied Finance and Banking, 2(2), 289-312.

Paradi, J. C., S. Rouatt and H. Zhu. (2011). Two-stage evalution of bank branch efficiency using data envelopment analysis. Omega, 39, 99-109. http://dx.doi.org/10.1016/j.omega.2010.04.002 
Pasiouras, F. (2008). International evidence on the impact of regulations and supervision on banks' technical efficiency: an application of two-stage data envelopment analysis. Review of Quantitative Finance and Accounting, 30(2), 187-223. http://dx.doi.org/10.1007/s11156-007-0046-7

Sathye, M. (2001). X-efficiency in Australian banking: an empirical investigation. Journal of Banking and Finance, 25(3), 613-630. http://dx.doi.org/10.1016/S0378-4266(00)00156-4

Sexton, T.R., \& H.F. Lewis. (2003). Two-stage DEA :an application to major league baseball. $\begin{array}{llll}\text { Journal of } \quad \text { Productivity } & \text { Analysis, } 27-249 \text {. }\end{array}$ http://dx.doi.org/10.1023/A:1022861618317

Shaffnit, C., D. Rosen, \& J.C. Paradi. (1997). Best practice analysis of bank branches: an application of DEA in a large Canadian bank. European Journal of Operational Research, 98(2), 269-289. http://dx.doi.org/10.1016/S0377-2217(96)00347-5

Sharma, S.K.., \& R. Dalip. (2014). Efficiency and productivity analysis of Indian banking industry using Hicks-Moorstreen approach. International Journal of Productivity and Performance Management, 63(1), 57-84. http://dx.doi.org/10.1108/IJPPM-09-2012-0096

Sufian, F. (2009). The impact of the Asian financial crisis on bank efficiency: the 1997 experience of Malaysia and Thailand. Journal of International Development, 22(7), 866-889. http://dx.doi.org/10.1002/jid.1589

Williams, J., \& N. Nguyen. (2005). Financial liberalisation, crisis, and restructuring: a comparative study of bank performance and bank governance in South East Asia. Journal of Banking and Finance, 29(8-9), 2119-2154. http://dx.doi.org/10.1016/j.jbankfin.2005.03.011

Zenios, C.V., S.A. Zenios, K. Agathocleous, \& A. Soteriou. (1999). Benchmarks of the efficiency of bank branches. Interfaces, 29(3), 37-51. http://dx.doi.org/10.1287/inte.29.3.37

Zhu, J. (2000). Multi-factor performance measure model with an application to fortune 500 companies. European Journal of Operational Research, 123(1), 105-124. http://dx.doi.org/10.1016/S0377-2217(99)00096-X 